\title{
Evaluating the impacts of forest fire on the vegetation of sub-tropical Chir pine forest in district Mansehra, Pakistan
}

\author{
Syed Lateef Hussain ${ }^{1 *}$, Ahmad Hussain ${ }^{1}$, Saleem khan ${ }^{1}$ and Salman \\ $\mathrm{Khan}^{2}$
}

1. Department of Forestry and Wildlife Management, University of Haripur, Pakistan

2. Department of Environmental Sciences, University of Haripur, Pakistan

*Corresponding author's email: slhussain83@gmail.com

Citation

Syed Lateef Hussain, Ahmad Hussain, Saleem khan and Salman Khan. Evaluating the impacts of forest fire on the vegetation of sub-tropical Chir pine forest in district Mansehra, Pakistan. Pure and Applied Biology. Vol. 5, Issue 1, 2016, pp 102-106. http://dx.doi.org/10.19045/bspab.2016.50013

Received: 17/11/2015 Revised: 02/01/2016

Accepted: 05/01/2016

Online First: 09/01/2016

\section{Abstract}

Floral diversity and Chir Pine (Pinus roxburghii) regeneration and growth status in burned and unburned areas were compared to quantify the impacts of fire on sub-tropical Chir pine forest type. The overall results of the study show that forest fires have adverse effects on plant diversity and Chir Pine regeneration and growth. Significant differences were observed in species diversity and evenness while comparing burned and unburned areas vegetations. The resultant values of diversity and evenness indices for tree and shrub species are high in unburned forest areas as compared to the burned forestland. While value of diversity index for herbaceous species is high in fire affected forest areas than unburned forestland whereas evenness index is high in unburned forest areas. Chir pine natural regeneration and growth in the two forestlands were also better in unburned areas as compared to burned. Total numbers of seedlings, saplings and pole regeneration were 759 and 897 in fire affected and unaffected plots respectively. Also the resultant values of trees diameter and height growth in both areas show that total increment gained by burnt trees in last ten years was less than total increment gained by unaffected trees.

Key words: Pinus roxburghii; Species diversity; Chir pine regeneration

\section{Introduction}

Forest fires have numerous implications for biological diversity. At the global level they are major source of emitted carbon, contributing to global warming which might lead to changes in biodiversity; while at local and regional scale they reduce biomass stocks, alter the hydrological cycle with consequent effects for marine ecosystems [1].
Globally the total area burnt by forest fires in 1997 to 98 was about 14.4 million hectares and emits 41 million tons of carbon dioxide while in South East Asia 4.66 million hectares area burnt and 11 million tons of carbon dioxide produced [2]. From 1998 to 2002, forest fires damages approximately 27.74 million hectares area globally, in which $43 \%$ area belongs to Asia [3]. 
The effects of forest fire are more than tree damage; fire caused alterations in ecosystem which results in both relief and stress to plant and animal life [4]. Humans have used fire as a land management tool for thousands of years, but in the latter part of the twentieth century, an increase in El Niño frequency and changes in the human-fire dynamic have led to a situation where forest fires are now a main threat to many forest ecosystems and the biodiversity therein [5]. The forests of Pakistan are constantly on decline due to many reasons but fire is one of the main factors of environment and forest degradation [6].

The Himalayan subtropical Pine forests are a large subtropical coniferous forest ecoregion covering portions of Bhutan, India, Nepal, and Pakistan [7]. Chir Pine (Pinus roxburghii) is the dominant species in these subtropical Pine forests, which is one of the most divergent and economically important plant species, providing valuable timber, fuel, resin and protect watersheds to sustain the water supply to millions residing in the Himalayan basin [8].

The occurrence of fires in Chir Pine forests is a regular and common phenomenon. Most frequently the fires are deliberately set by the local people in order to get the forest floor clear of Pine needles and to obtain a good growth of grass which comes up abundantly in new flush after burning [9, 10]. Though fire is mentioned as hazard in forestry related studies conducted in Pakistan, but has not been evaluated to identify its impacts [6].

Therefore the main purpose of this study is to evaluate and quantify the impacts of fire on the vegetation of sub tropical Chir Pine forest. This is because before taking any remedial steps we must know the amount of damage done.

\section{Material and Methods}

Study area: Mansehra district lies from $34^{\circ}$ - $14^{\prime}$ to $35^{\circ}-11^{\prime}$ north latitudes and $72^{\circ}$ - $49^{\prime}$ to $74^{\circ}-08^{\prime}$ east longitudes. Its total area is $4,579 \mathrm{~km}^{2}$ or 457900 ha out of which 332252 ha area is under forest. The district is dominated by high mountains and varying in elevations from $4500 \mathrm{~m}$ in the north to $2000 \mathrm{~m}$ in the south above sea level. Because of this huge variation in elevation ecologically the district fall in Sub Tropical and Temperate zones with major land use as agriculture, forest, grasslands, sub alpine and alpine pastures [11].

Sampling and Data collection: The occurrence of fire in a forest area is not uniformly distributed and is present in patches, scattered throughout the forest area, therefore, only random sampling design can be applied. In the study fire affected areas are randomly selected, and compared with adjacent area with no fire damages (control area). Before selecting the areas a reconnaissance survey was conducted to make sure that factors like aspect, altitude, slope, site quality and silvicultural system applied must be same in both land sites. Due to limited time and resources available for the study 28 sample plots in burned and adjacent 28 sample plots in unburned areas were measured randomly with $5 \%$ sampling intensity throughout the sub-tropical Chir pine forest of district Mansehra. Field inventory method was used in accordance with vegetation description and analysis method [12]. Plots of different size and shape with same centre point were used for each type of vegetation i.e. 0.1 ha for trees, for shrubs quadrate $5 \times 5 \mathrm{~m}$ and $1 \times 1 \mathrm{~m}$ for herbs and grasses.

Species diversity: To compare species diversity in the burned and unburned areas Shannon diversity index and Shannon evenness index, Sorenson's similarity index and Species Richness indices were used [13].

Regeneration Status: To find out the status of Pine regeneration in both the areas, circular plots of $100 \mathrm{~m}^{2}$ were selected, in 
which number of seedlings, samplings and poles were counted and compared.

Pine Trees Growth: To evaluate the effect of fire on Chir Pine trees growth, trees of same DBH (Diameter at Breast Height) were taken from both areas and their height and last ten years increment were compared. Tree height was measured with help of Haga altimeter while Pressler's Borer (increment borer) was used to find out diameter increment [14].

\section{Result and discussion}

Species diversity: A total of 33 tree and shrub species were found in unburned areas while 27 in burned areas and in case of herbs and grasses 17 and 14 species were identified in burned and unburned areas respectively. Significant differences were observed in species diversity and evenness while comparing burned and unburned areas vegetations. The resultant values of diversity and evenness indices for tree and shrub species are high in unburned forest areas as compared to the burned forestland. While value of diversity index for herbaceous species is high in fire affected forest areas as compared to the unburned forestland whereas evenness index is high in unburned forest areas as given in Table 1.

Table 1. Diversity Indices for Tree/Shrub and Herbaceous Species

\begin{tabular}{|l|c|c|c|c|}
\hline \multirow{2}{*}{\multicolumn{1}{|c|}{ Diversity Index }} & \multicolumn{2}{|c|}{ Trees and shrub species } & \multicolumn{2}{c|}{ Herbaceous species } \\
\cline { 2 - 5 } & $\begin{array}{c}\text { Unburned } \\
\text { Areas }\end{array}$ & Burned Areas & $\begin{array}{c}\text { Unburned } \\
\text { Areas }\end{array}$ & $\begin{array}{c}\text { Burned } \\
\text { Areas }\end{array}$ \\
\hline Shannon diversity index & 3.0211 & 2.7637 & 2.4446 & 2.6620 \\
\hline Shannon evenness index & 0.864 & 0.838 & 0.9263 & 0.6944 \\
\hline Species Richness index & 1.14 & 1.06 & 1.83 & 1.97 \\
\hline $\begin{array}{l}\text { Sorenson's similarity } \\
\text { index }\end{array}$ & \multicolumn{2}{|c|}{$\begin{array}{c}0.8 \text { or } 80 \% \text { similarity in } \\
\text { vegetation composition of both } \\
\text { areas (20\% Differences) }\end{array}$} & $\begin{array}{c}0.83 \text { or 83 \% similarity in } \\
\text { vegetation composition of both } \\
\text { areas (17\% Differences) }\end{array}$ \\
\hline
\end{tabular}

Note: In Shannon diversity index significant difference was observed with t-test even at $99 \%$ confidence level the resultant $\mathrm{t}$ value for Tree/shrub species is $\mathrm{t}=4.93$ and for Herbaceous species $\mathrm{t}=2.34$ while $\mathrm{t}_{0.99}$ $=2.33$

Regarding similarity in vegetations of both areas, herbaceous vegetation shows high value of similarity index with $17 \%$ differences than tree/shrub species having $20 \%$ differences. The resultant values for richness in species composition indicate that unburned areas are richer in species composition than burned areas regarding trees and shrub vegetation. While on the other hand herbaceous vegetation has high value of species richness index on fire affected areas.

\section{Chir pine regeneration status}

The number of seedlings, saplings and poles in each of the 20 burned and unburned sample plots were counted and summed.
The total numbers of individuals in all sample plots are given in Table 2 .

The pie-charts in Fig. 1 of both forestlands show that percentage of seedlings is high in burned plots whereas saplings and pole regeneration have high percentages in unburned plots. In burned areas as a result of forest fire a thick layer of Pine needles which cover the forest floor had burnt and the ground was cleared for Pine seed germination and for other herbaceous vegetation. Which also increases the grazing pressure in burned forest areas and the young seedlings were badly damaged. Further repeated fires also restricted the development of seedlings to sapling stage. 
Table 2. Chir pine regeneration status

\begin{tabular}{|l|c|c|}
\hline \multicolumn{1}{|c|}{ Regeneration Stage } & $\begin{array}{c}\text { Number of individuals in } \\
\text { Burned Plots }\end{array}$ & $\begin{array}{c}\text { Number of individuals in } \\
\text { Unburned Plots }\end{array}$ \\
\hline Seedlings & 616 & 461 \\
\hline Saplings & 109 & 322 \\
\hline Poles $\quad$ Total & 34 & 114 \\
\hline \multicolumn{1}{|c|}{} & $\mathbf{7 5 9}$ & $\mathbf{8 9 7}$ \\
\hline
\end{tabular}

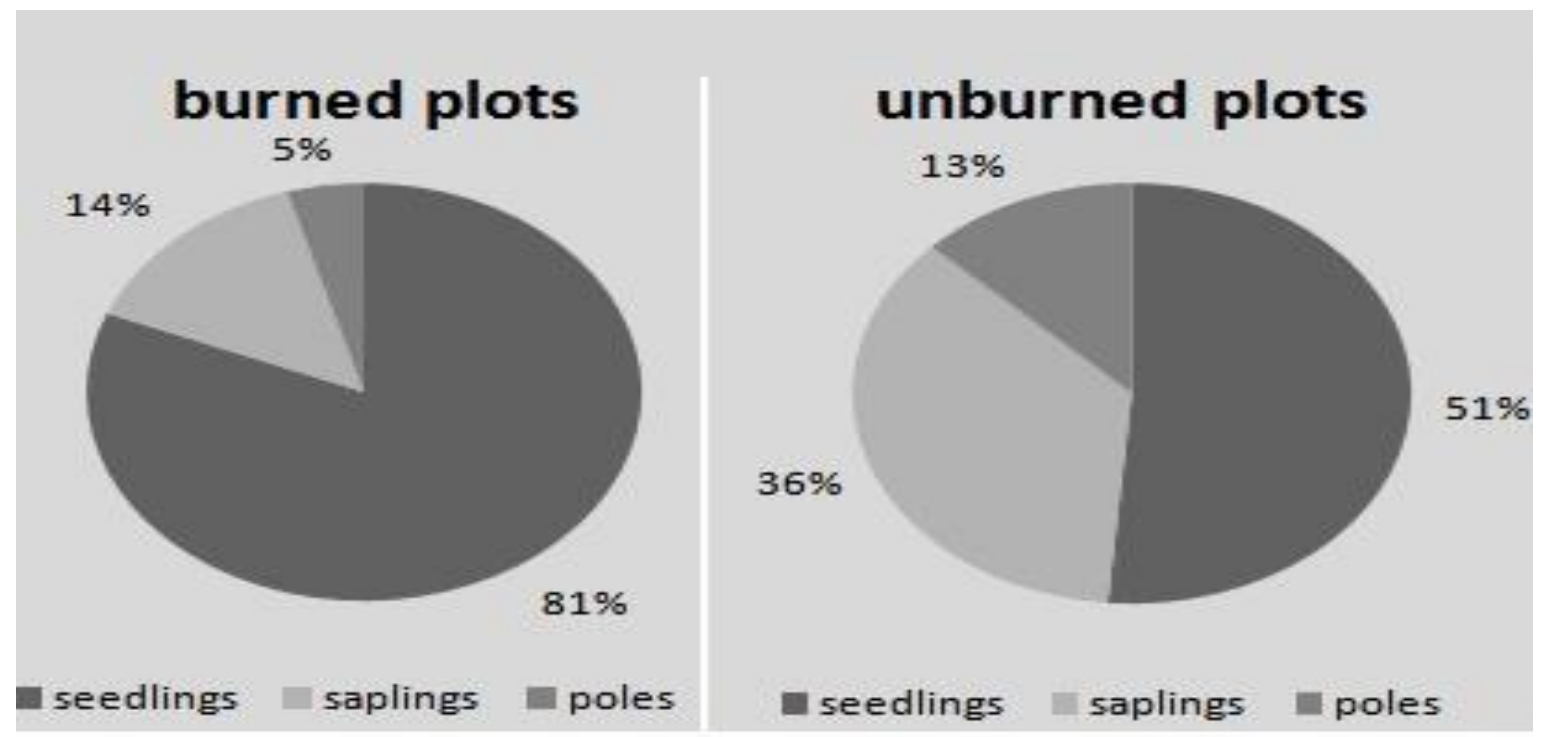

\section{Figure 1. Comparison of Chir pine regeneration}

\section{Pine Trees Growth}

The effects of forest fire on Chir pine tree growth in the two forestlands repeated the same story. The difference in total diameter increments gained by 20 trees in last ten years of each forestland is about $7.6 \mathrm{~cm}$ but for a whole forest stand this difference will become a huge volume of wood, which is destroyed by fires. A considerable difference was also observed in height growth of burnt and unburned trees. The difference in height of just 20 trees of same diameter in each forest area is about 83 meters while considering the whole Chir pine forest of the study area this difference will become a huge loss of wood. Further it was also noted that diameter and height growth of young trees were more effected by forest fires as compared to matured trees.

\section{Conclusion}

It has been concluded from this study that forest fires have adverse impacts on the vegetation of sub-tropical Chir pine forest regarding its plant species diversity and Chir pine regeneration and growth.

\section{Authors' contributions}

Conceived and designed the experiments: SL Hussain \& A Hussain. Performed the experiments: SL Hussain \& S Khan, Analyzed the data: S Khan, SL Hussain \& S Khan, Contributed reagents/ materials/ analysis tools: SL Hussain, S Khan \& A Hussain, Wrote the paper: SL Hussain \& A Hussain.

\section{Acknowledgements}

We are thankful to the field staff of Siran Forest Division and Agror Tanawal Forest 
Division, Mansehra for their great support in the data collection for the study.

\section{References}

1. Davies SJ \& Unam L (1999). Smoke-haze from the 1997 Indonesian forest fires; effects on pollution levels, local climate, atmospheric $\mathrm{CO}_{2}$ concentrations and tree photosynthesis. For Ecol Manage 124: 137-144.

2. International Union for the Conservation of Nature (IUCN) \& World Wide Fund for Nature (WWF) (2000). Global review of forest fires. Gland, Switzerland.

3. FAO (2006). Global Forest Resource Assessment 2005. FAO Forestry Paper 147: 64-65.

4. Khan RH (2003). Foest Fire Control. Muzaffarabad, Azad Jammu and Kashmir. Riaz Printers; Mirpur (Pakistan). 1-12.

5. FAO (2001). Global Forest Resource Assessment 2000. FAO Forestry Paper 140: 189-191.

6. Iqbal M (2003). Deforestation in NWFP. National Institute of Public Administration (NIPA), Karachi. 8(3): 26-30.

7. Champion HG, Seth SK \& khattak GM (1965). Forest Types of Pakistan. Pakistan Forest Institute, Peshawar. 141-151.
8. Gupta B, Mehta R \& Mishra VK (2009). Fire Ecology of Ground Vegetation in Pinus roxburghii Sargent Plantations in North-West Himalaya-Floristic Composition and Species Diversity. Caspian J Env Sci 7: 71-78.

9. Mahmud N (1998). Revised Working Plan for Giddarpur Forest of Agror Tanawal Forest Division, District Mansehra (Pakistan). 12-15.

10. Muhammad SA, Malik ZH, Malik NZ \& Sadia MA (2012). The position of Pinus roxburghii in the forests of Kotli hills, Azad Jammu and Kashmir. Afri $J P l$ Sci 6(3): 106-112.

11. DCR (1998). District Census Report of Mansehra District by Statistics Division Government of Pakistan. 3-16

12. Kent M \& Coker P (1992). Vegetation Description and Analysis. A Practical Approach. Belhaven Press; London. 1128.

13. Jayaraman K (1999). A statistical manual for forestry research. FAO Forestry Research Support Programme for Asia and Pacific. 191-197.

14. Buechling A \& Baker WL (2004). A fire history from tree rings in a highelevation forest of Rocky Mountain National Park. Can J For Res 34(6): 1259-1273. 